\title{
Antimicrobial materials properties based on ion-exchange 4A zeolite derivatives
}

\author{
Willian A. Cardoso ${ }^{1}$, Geovana D. Savi ${ }^{1 *}$, Ana Carolina Feltrin ${ }^{1}$, Carolina R.M. Marques ${ }^{2}$, Everton \\ Angioletto ${ }^{1}$, Claus T. Pich ${ }^{3}$, Reginaldo Geremias ${ }^{3}$, Erlon Mendes ${ }^{1}$ and Elidio Angioletto ${ }^{1}$ \\ ${ }^{1}$ Universidade do Extremo Sul Catarinense - Rodovia Governador Jorge Lacerda, Km 4,5, Sangão, CEP: 88806-000, \\ Criciúma, Santa Catarina, Brasil \\ ${ }^{2}$ Bairro Universitário, Faculdade SATC - Rua Pascoal Meller, 73, CEP 88805-380, Criciúma, Santa Catarina, Brasil \\ ${ }^{3}$ Universidade Federal de Santa Catarina; Centro de Ciências, Tecnologias e Saúde; Departamento de Energia e Susten- \\ tabilidade; Rod. Gov. Jorge Lacerda 3201; CEP 88906-072, Araranguá, Santa Catarina, Brasil \\ "Corresponding author: e-mail: geovanasavi@gmail.com
}

\begin{abstract}
Zeolites are nanoporous alumina silicates in a framework with cations, exhibiting ion-exchange properties with metal ions making them possible antimicrobial materials. The aim of this study was to evaluate the antimicrobial activity of ion-exchanged zeolites and the toxic potential of these materials. Zeolite- $\mathrm{Co}^{2+}$ and $\mathrm{Li}^{+}$exhibited the most effective inhibition on Staphylococcus aureus growth than in other microorganisms (Escherichia coli and Pseudomonas aeroginosa) in low concentrations. Zeolite- $\mathrm{Cu}^{2+}$ presented higher zone of inhibition when tested against Candida albicans, while Zeolite- $\mathrm{Zn}^{2+}$ showed similar effectiveness among all the microorganisms. When ion-exchanged zeolites were used in effective concentrations to achieve antimicrobial activity, no alterations against bioindicators organisms as Artemia sp. and L. sativa were found and, in addition, they have non-significant result in terms of DNA cleavage activity. Zeolites have advantage of releasing slowly the metals loaded and this characteristic can to be considered promising as potential antimicrobial materials in concentrations safe for use.
\end{abstract}

Keywords: antimicrobial, zeolite, ion-exchange, bacteria, yeast.

\section{INTRODUCTION}

The occurrence of adverse effects caused by the use of conventional antimicrobial agents, which ones have developed resistance to antibiotics and disinfectants, encourage the emergence and improvement of new materials with antimicrobial properties. New types of safe and cost-effective antimicrobial materials have been of great interest due to their several applications, especially in the area of medical devises and food packing and storage $^{\mathbf{1}, \mathbf{2}}$. For this reason, the development of antimicrobial packaging systems is a crucial strategy for improving the food shelf-life. An example is eugenol-bearing L malic acid-derived or carboxyanhydrides, which showed antimicrobial activity against pathogenic bacteria (Staphylococcus aureus, Pseudomonas aeroginosa and Escherichia coli), making them promising for developments of bioactive and biodegradable polylactic acid based materials ${ }^{3}$. Moreover, previous studies have already showed that bulk or surface modifications with silver significantly improved the antimicrobial properties of polylactide films. These modified films were particularly efficient against $E$. coli, Listeria monocytogenes and Salmonella typhimurium bacteria, but were less efficient in the growth inhibition of $S$. aureus ${ }^{4}$. The use of materials that exhibit antimicrobial activity due to the oligodynamic effect can help to reduce, mitigate or even eradicate some of these contaminations and infections, resulting in improving public health ${ }^{5}$.

Zeolites are very important in the development of functional materials and are considered a promising substrate due to their unique features such as high ion exchange capacity, high surface area, hydrophilicity and easily tunable chemical properties ${ }^{6-8}$. Zeolites are alumina silicates composed of $\mathrm{SiO}_{4}$ and $\mathrm{AlO}_{4}$ tetrahedral structure, in which the anionic characteristic is counteracted by cations outside the molecule. It is possible to obtain synthetic zeolites, such as $4 \mathrm{~A}$, from kaolin; a mineral clay characterized as one hydrated aluminium silicate with a composition similar to $\mathrm{Al}_{2} \mathrm{Si}_{2} \mathrm{O}_{5}(\mathrm{OH})_{4}$.

The characteristic composition of $4 \mathrm{~A}$ zeolites is $\mathrm{Na}_{12}[\mathrm{Al}-$ $\left.{ }_{12} \mathrm{Si}_{12} \mathrm{O}_{48}\right] 27 \mathrm{H}_{2} \mathrm{O}$ and it allows cationic exchange procedures. Synthetic and natural zeolites have also been targeted for antibacterial use by cation exchange process, especially after ion-exchange with metals such as silver, zinc, copper and others ${ }^{2,10-12}$. Antibacterial metals loaded onto zeolites are released slowly and act as inorganic bactericide and disinfectants, which are excellent in terms of safety and thermal stability when compared to organic ones ${ }^{13}$.

Considering that antimicrobial metals show important advantages over traditionally used organic agents and that the zeolites have been considered a promising metal reservoir, the interest of this study was to evaluate the $4 \mathrm{~A}$ zeolite exchanged with several ions as $\mathrm{Cu}^{2+}$, $\mathrm{Zn}^{2+}, \mathrm{Co}^{2+}, \mathrm{Li}^{+}, \mathrm{La}^{3+}$ and $\mathrm{Ce}^{3+}$ as antimicrobial agents against three bacteria including $S$. aureus, E. coli and $P$. aeruginosa and the yeast Candida albicans.

These microorganisms were selected due to the fact that they are existent in several environments and when present in food, water or medical materials, can compromise the quality of the product as well the human health. In addition, no study has examined the antimicrobial effect of $4 \mathrm{~A}$ zeolite exchanged with ions such as $\mathrm{Co}^{2+}$, $\mathrm{Li}^{+}, \mathrm{La}^{3+}$ and $\mathrm{Ce}^{3+}$ as proposed by this study.

In addition, the study evaluated the toxic potential of these materials within the effective concentrations to antimicrobial activity against bioindicators organisms as Artemia sp. and L. sativa and also on plasmid DNA cleavage. Some metals used in the ion-exchanged zeolites are essential to life and play important role in the human metabolic system, but it can harm the living organisms in excessive level. Therefore, it is important to investigate the toxic effects of these compounds through toxicity assays. 


\section{MATERIALS AND METHODS}

\section{Chemicals}

The $\mathrm{NaNO}_{3}, \mathrm{CuCl}_{2}, \mathrm{ZnCl}_{2}, \mathrm{LaCl}_{3}, \mathrm{LiOH} . \mathrm{H}_{2} \mathrm{O}$, $\mathrm{CoSO}_{4} \cdot 7 \mathrm{H}_{2} \mathrm{O}, \mathrm{CeCl}_{3} .7 \mathrm{H}_{2} \mathrm{O}$ used for ion-exchange process, were purchased from Vetec (Duque de Caxias, RJ, Brazil). Agarose and ethidium bromide (EB) from Sigma Aldrich Chemicals (St. Louis, MO, USA). The culture medium plate count agar (PCA), Luria Bertani (LB), Saboraud dextrose agar (SDA) and brain heart infusion (BHI) were supplied by Himedia Laboratories (Bhaveshwar Plaza, Mumbai, India). The synthetic sea salt from Norsal (São Paulo, SP, Brazil). Artemia sp. and L. sativa were acquired from Bio Pet Food (Guarulhos, SP, Brazil) and Feltrin Sementes Ltda. (Farroupilha, RS, Brazil), respectively. All were purchased from commercial sources and were analytical grade. The pBSK-II plasmid DNA, used for cleavage assays, was purchased from Stratagene (San Diego, California, EUA).

S. aureus CCCD S007, E. coli CCCD E003, P. aeruginosa CCCD P003 and C. albicans CCCD CC001 strains were obtained from Cefar (São Paulo, SP, Brazil).

\section{Ion-Exchange of 4A Zeolite}

As a base material, previously synthesized 4A zeolite (100 g) was employed from commercial kaolin'. The cations used for ion-exchange $\left(\mathrm{Cu}^{2+}, \mathrm{Zn}^{2+}, \mathrm{Co}^{2+}, \mathrm{Li}^{+}, \mathrm{La}^{3+}\right.$ and $\mathrm{Ce}^{3+}$ ) were chosen because of their antimicrobial characteristics $^{\mathbf{1 4}, \mathbf{1 5}}$. For each ion, the maximum exchange rate was $24 \%$ of the sodium present in the zeolite. Sodium nitrate $\left(\mathrm{NaNO}_{3}\right)$ was used as a carrier for the $\mathrm{Cu}^{2+}, \mathrm{Zn}^{2+}$, $\mathrm{Li}^{+}$and $\mathrm{La}^{3+}$ ions in the formulations presented in Table 1. The $\mathrm{Co}^{2+}$ and $\mathrm{Ce}^{3+}$ ions did not require a carrier once the amount of reactants exceeded the zeolite mass, and the fusion temperature of these ions is lower than that of $\mathrm{NaNO}_{3}(581 \mathrm{~K})$. The mixtures were homogenized and heated for $2 \mathrm{~h}$ at the temperatures listed in Table 1. After cooling to room temperature, the mixtures were washed with deionized water ( $1 \mathrm{~L})$ and finally dried.

The zeolites were previously characterized ${ }^{\mathbf{1 6}}$ by X-ray fluorescence (XRF, APW 2400 Philips) and atomic absorption spectrophotometry (AAS, AA240FS Fast Sequential). For X-ray diffraction (XRD), a Schimadzu XRD 6000 equipped with a copper tube was used with a current of $30 \mathrm{~mA}$ and potential difference of $30 \mathrm{kV}$. The phases were identified by comparing the collected full-set diffraction patterns maintained by the Joint Committee on Powder Diffraction Standards (JCPDS). For the FTIR analyses, a Schimadzu IR Prestige 21 was used. The tablets were prepared in $\mathrm{KBr}$ with the zeolite at concentration of $1 \%$, and spectra were obtained over the range of 4000 to 400 $\mathrm{cm}^{-1}$. The scanning electron microscopy (SEM) image was obtained using Zeiss equipment, with a current of $30 \mathrm{~mA}$ and potential difference of $30 \mathrm{kV}$.

\section{Microbiological assay}

\section{Agar diffusion test}

The modified disc diffusion method was performed according to the recommendation of Clinical and Laboratory Standards Institute (CLSI) methodology, approved standards M02-A10 ${ }^{17}, 18$. The inoculum for the agar diffusion method was prepared with growing $S$. aureus, E. coli, $P$. aeruginosa and $C$. albicans, separately, to the turbidity standards. Therefore, five well-isolated colonies of the same morphology type were selected from a PCA (used to grow bacteria) and SDA (used to grow yeast) plate culture grown by 24 to $48 \mathrm{~h}$ and transfer into a tube containing 5 $\mathrm{mL}$ of saline. The suspension was adjusted until reach the turbidity standard (measured by absorbance at $625 \mathrm{~nm}$ ) from 0.08 to $0.13\left(10^{8} \mathrm{CFU} / \mathrm{mL}\right)$ for the microorganism, equivalent to a 0.5 MacFarland standard. Within $15 \mathrm{~min}$ after adjusting the turbidity of the inoculum suspension, a sterile cotton swab was dipped into the suspension and spread on the entire sterile agar surface using the same media culture for each microorganism. The medium surface was allowed to dry and the six materials (4A zeolite with $\mathrm{Cu}^{2+}, \mathrm{Zn}^{2+}, \mathrm{Co}^{2+}, \mathrm{Li}^{+}, \mathrm{La}^{3+}, \mathrm{Ce}^{3+}$ ) were tested, as well as a negative control consisting of $4 \mathrm{~A}$ zeolite without ion exchange (55.5 mg each). All plates were incubated $24 \mathrm{~h}$ at $310 \mathrm{~K}$ and $300 \mathrm{~K}$ for bacterial and yeast, respectively. After incubation, the presence of the growth inhibition zone around the antimicrobial materials samples was observed and its diameter was measured in millimeters. All experiments were performed in triplicate.

\section{Microorganism cell survival assay}

The survival of the microorganisms was observed in different concentrations of the materials tested through of growth inhibition. The survival rate was determined in broth culture containing the antimicrobial materials ${ }^{\mathbf{1 8}, 19}$. The materials, 4A zeolite (negative control) and ion-exchanged ones $\left(\mathrm{Cu}^{2+}, \mathrm{Zn}^{2+}, \mathrm{Co}^{2+}, \mathrm{Li}^{+}, \mathrm{La}^{3+}\right.$ and $\left.\mathrm{Ce}^{3+}\right)$ were then tested in triplicate at concentrations of 166.6, $96.2,78.5,55.5,32.1,26.2,18.5,10.7,6.2,3.6,2.1,1.2$ and $0.7 \mathrm{mg} / \mathrm{mL}$ in a total volume of $3 \mathrm{~mL}$. In the sequence, $300 \mu \mathrm{L}$ of microorganisms at a concentration of $10^{5} \mathrm{CFU} / \mathrm{mL}$ were inoculated in $2.7 \mathrm{~mL}$ of $\mathrm{LB}$ medium for bacteria growth and in $\mathrm{BHI}$ medium for yeast growth. Subsequently, the 4A zeolite and ion-exchanged zeolites were added, and the mixtures incubated for $24 \mathrm{~h}$ at $310 \mathrm{~K}$ and $300 \mathrm{~K}$, respectively. After this, 50 $\mu \mathrm{L}$ aliquots of each sample were applied on PCA or SDA and incubated again for $24 \mathrm{~h}$ at $310 \mathrm{~K}$ and $300 \mathrm{~K}$ for bacterial and yeast growth, respectively. Finally, the number of colonies was counted and the average CFU per $\mathrm{mL}$ was determined.

Table 1. Composition of the mixtures used to ion exchange procedure in the 4A zeolite samples

\begin{tabular}{|c|c|c|c|c|c|}
\hline Ion & Reagent & Mass, $\mathrm{g}$ & Vehicle $\mathrm{NaNO}_{3}, \mathrm{~g}$ & $\begin{array}{c}\text { Mass of zeolite, } \\
\mathrm{g}\end{array}$ & Temperature, $\mathrm{K}$ \\
\hline $\mathrm{Cu}^{2+}$ & $\mathrm{CuCl}_{2}$ & 35.0 & 70.0 & 100.0 & 603 \\
\hline $\mathrm{Zn}^{2+}$ & $\mathrm{ZnCl}_{2}$ & 30.0 & 70.0 & 100.0 & 603 \\
\hline $\mathrm{Li}^{+}$ & $\mathrm{LiOH} . \mathrm{H}_{2} \mathrm{O}$ & 63.2 & 50.0 & 100.0 & 773 \\
\hline $\mathrm{La}^{3+}$ & $\mathrm{LaCl}_{3}$ & 53.0 & 50.0 & 100.0 & 603 \\
\hline $\mathrm{Ce}^{3+}$ & $\mathrm{CeCl}_{3} .7 \mathrm{H}_{2} \mathrm{O}$ & 124.0 & - & 100.0 & 373 \\
\hline
\end{tabular}




\section{Toxicological assays}

\section{Toxicity assay with Artemia sp.}

The evaluation of cytotoxicity of the zeolites samples in Artemia sp. was performed according to previous methods ${ }^{\mathbf{2 0}, 21}$. A solution of salt water was prepared with synthetic sea salt $(30 \mathrm{~g} / \mathrm{L})$ and used as the incubation medium for the cysts of Artemia sp. Young individuals $(\mathrm{n}=10)$ were exposed 4A zeolite (negative control) and ion-exchanged with $\mathrm{Cu}^{2+}, \mathrm{Zn}^{2+}, \mathrm{Co}^{2+}$ and $\mathrm{Li}^{+}$in multi-well plates with $2 \mathrm{~mL}$ at concentrations of 166.6, $96.2,78.5,32.1,18.5,10.7,6.2,3.6,2.1,1.2 \mathrm{mg} / \mathrm{mL}$ in four replicates. After $24 \mathrm{~h}$ of exposure, the number of dead organisms was observed and noted and the results were expressed as mean \pm standard deviation.

\section{Lactuca sativa seed germination}

The germination of L. sativa seeds assay was performed according to Charles et al. (2011) ${ }^{22}$ with minor modifications. Seeds $(n=10)$ were disposed on germination paper soaked with $2 \mathrm{~mL}$ of the $4 \mathrm{~A}$ zeolite and ion-exchanged with $\mathrm{Cu}^{2+}, \mathrm{Zn}^{2+}, \mathrm{Co}^{2+}$ and $\mathrm{Li}^{+}$in a Petri dish $(90 \mathrm{~mm})$ at $295 \mathrm{~K}$ in the dark. The treatments were arranged in a completely random design with three replications for each concentration (166.6, 96.2, 78.5, $32.1,18.5,10.7,6.2,3.6,2.1,1.2 \mathrm{mg} / \mathrm{mL})$. Percentage of germinated seeds and the hypocotyl and radicle (root) growth were determined $72 \mathrm{~h}$ after initial exposure and then compared to the control group (without zeolite) ${ }^{\mathbf{2 2}}$. Results were expressed as mean \pm standard deviation.

\section{Plasmid DNA cleavage assay}

To assess the nuclease activity of the zeolites, plasmid DNA cleavage assay was performed according to Netto et al. (2013) ${ }^{\mathbf{2 3}}$ with adaptations. The concentrations of 0 (negative control), $12.5,25$, and $50 \%$ of the stock solutions of 4A zeolite $(166 \mathrm{mg} / \mathrm{mL})$ and ion-exchanged with $\mathrm{Cu}^{2+}(32 \mathrm{mg} / \mathrm{mL}), \mathrm{Zn}^{2+}(166.6 \mathrm{mg} / \mathrm{mL}), \mathrm{Co}^{2+}(18.5$ $\mathrm{mg} / \mathrm{mL}), \mathrm{Li}^{+}(18.05 \mathrm{mg} / \mathrm{mL})$ were incubated in $20 \mu \mathrm{L}$ of a water solution containing pBSK-II plasmid DNA (300 ng) and $10 \mathrm{mM}$ of HEPES buffer ( $\mathrm{pH} \mathrm{7.4)} \mathrm{for} 16$ $\mathrm{h}$ at $310 \mathrm{~K}$. Subsequently, these solutions were loaded onto $1 \%$ agarose gels containing ethidium bromide (EB), and after electrophoresis, bands corresponding to supercoiled form (uncleaved - FI), open circular form (single strand cleaved - II) and the linear form (double strand cleaved - FIII) were photo documented when present. Fluorescence intensity of EB stained bands was measured with Gel Analiser ${ }^{\circledR}$ free version program. The experiments were performed in triplicate and the results were expressed as mean \pm standard deviation.

\section{Statistical analysis}

Statistical analyses were performed using Analysis of Variance (ANOVA), followed by Bonferroni post-test in GraphPad Prism 5.0 software. The results are presented as the mean and the standard deviation (SD) and the $p$ values $<0.05$ were considered statistically significant.

\section{RESULTS AND DISCUSSION}

\section{A Zeolite analysis}

The results obtained from the XRF analysis are presented in Table 2. The sodium content $\left(\mathrm{Na}_{2} \mathrm{O}\right)$ was $24.3 \%$ for the 4A zeolite (without ion-exchange), and this was used as a parameter for calculating the amounts of ions involved in the ion-exchange procedures. As shown in the same table, the substitution of the sodium content was almost complete for all ions used, with only two exceptions: $\mathrm{Zn}^{2+}$ and $\mathrm{La}^{3+}$.

The adsorption selectivity of cations is greatly influenced by pore size and specific hydrophilic capacity of the zeolites. If the volume of coordination sphere of hydrated cations to be added prevents the entry into the porous system, which may have occurred with the $\mathrm{Zn}^{2+}$ and $\mathrm{La}^{3+}$ ions, it is possible to adopt the ion exchange in solid state as an alternative.

In this case, the trituration of the transition metal salt with the dehydrated zeolite, followed by a heat treatment is sufficient for the occurrence of the ion-exchange process. Therefore, the ion-exchange in solid state when compared with the conventional method (i.e. in solution) is one alternative to introduce metal cations in zeolites, when the volume of the cation salvation sphere interferes in the ion-exchange process in solution ${ }^{24}$.

However, this method may be less efficient when compared to the conventional method, resulting in a lower exchange between these cations in substitution for sodium.

In Table 2 can also be observed the loss to fire. This loss is related to the content of water in $4 \mathrm{~A}$ zeolite,

Table 2. XRF and AAS of 4A zeolite (Z4A) before and after ion-exchange

\begin{tabular}{|c|c|c|c|c|c|c|c|}
\hline $\begin{array}{l}\text { Element, } \\
\% \text { mass }\end{array}$ & Z4A & $\mathrm{Z} 4 \mathrm{~A}+\mathrm{Cu}^{2+}$ & $\mathrm{Z} 4 \mathrm{~A}+\mathrm{Zn}^{2+}$ & $\mathrm{Z} 4 \mathrm{~A}+\mathrm{Co}^{2+}$ & $\mathrm{Z} 4 \mathrm{~A}+\mathrm{Li}^{+}$ & $\mathrm{Z} 4 \mathrm{~A}+\mathrm{La}^{3+}$ & $\mathrm{Z} 4 \mathrm{~A}+\mathrm{Ce}^{3+}$ \\
\hline $\mathrm{Al}_{2} \mathrm{O}_{3}$ & 28.2 & 23.38 & 22.3 & 25.53 & 32.54 & 21.97 & 28.60 \\
\hline $\mathrm{CaO}$ & 0.07 & $<0.05$ & $<0.05$ & $<0.05$ & 0.30 & 0.52 & $<0.05$ \\
\hline $\mathrm{Fe}_{2} \mathrm{O}_{3}$ & $<0.01$ & 0.18 & 0.21 & 0.24 & 0.32 & 0.18 & 0.16 \\
\hline $\mathrm{K}_{2} \mathrm{O}$ & 0.01 & 0.25 & 0.27 & 0.27 & 0.19 & 0.28 & 0.25 \\
\hline $\mathrm{MgO}$ & $<0.01$ & $<0.05$ & $<0.05$ & 0.11 & 0.19 & $<0.05$ & $<0.05$ \\
\hline $\mathrm{MnO}$ & $<0.01$ & $<0.05$ & $<0.05$ & 0.07 & $<0.05$ & $<0.05$ & $<0.05$ \\
\hline $\mathrm{Na}_{2} \mathrm{O}$ & 24.30 & 4.35 & 10.39 & 3.80 & 3.82 & 16.06 & 1.84 \\
\hline $\mathrm{P}_{2} \mathrm{O}_{5}$ & $<0.01$ & $<0.01$ & $<0.05$ & $<0.01$ & $<0.05$ & $<0.05$ & $<0.05$ \\
\hline $\mathrm{SiO}_{2}$ & 31.7 & 27.36 & 29.16 & 31.7 & 33.54 & 28.80 & 35.3 \\
\hline $\mathrm{TiO}_{2}$ & $<0.01$ & $<0.01$ & $<0.05$ & $<0.01$ & $<0.05$ & $<0.05$ & $<0.05$ \\
\hline $\mathrm{CuO}$ & 0.00 & 22.83 & 0.00 & 0.00 & 0.00 & 0.00 & 0.00 \\
\hline $\mathrm{ZnO}$ & 0.00 & 0.00 & 17.61 & 0.00 & 0.00 & 0.00 & 0.00 \\
\hline Lao & 0.00 & 0.00 & 0.00 & 0.00 & 0.00 & 10.47 & 0.00 \\
\hline $\mathrm{Li} 2 \mathrm{O}$ & 0.00 & 0.00 & 0.00 & 0.00 & 15.80 & 0.00 & 0.00 \\
\hline $\mathrm{Co}_{2} \mathrm{O}_{3}$ & 0.00 & 0.00 & 0.00 & 15.8 & 0.00 & 0.00 & 0.00 \\
\hline Loss fire & 13.30 & 17.54 & 19.93 & 16.80 & 11.59 & 20.15 & 17.55 \\
\hline
\end{tabular}


which in stoichiometric amount can reach up to $22 \%$ in mass. However, this amount depends on the $\mathrm{SiO}_{2} / \mathrm{Al}_{2} \mathrm{O}_{3}$ ratio. Other factors can act in this loss of mass, since it did not occur uniformly, being possible that during the ion exchange the structure of the zeolites may have undergone alteration, resulting in different proportions in the $\mathrm{SiO}_{2} / \mathrm{Al}_{2} \mathrm{O}_{3}$ ratio.

The morphology of 4A zeolite was showed in Figure 1 , which presents cubic crystals approximately $2 \mu \mathrm{m}$, typical of zeolites 4A. The ion-exchanged zeolites were characterized in our previous study ${ }^{16}$.

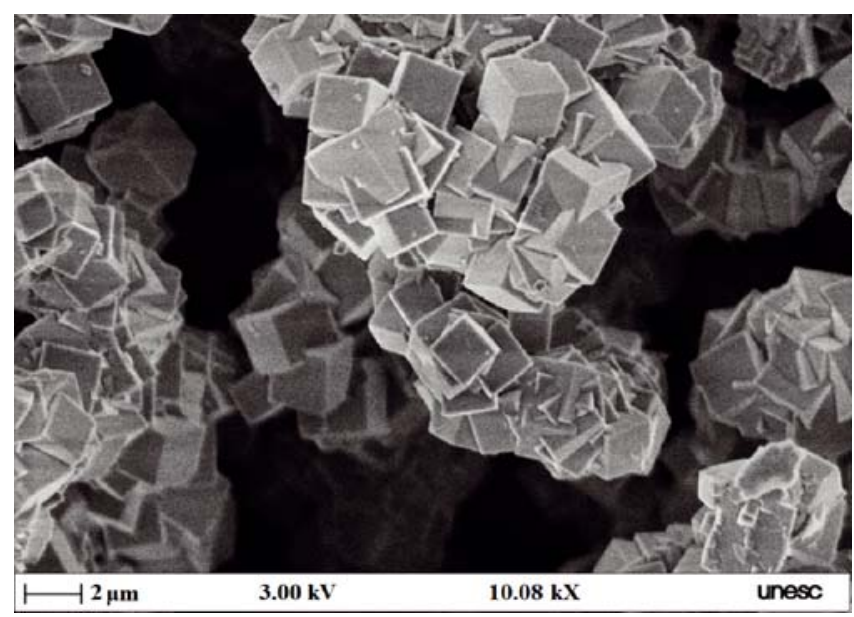

Figure 1. Morphology of $4 \mathrm{~A}$ zeolite. Scale bar $=2 \mu \mathrm{m}$. Magnification $=10.08 \mathrm{kX}$

\section{Antimicrobial activity}

The ion-exchange zeolites were evaluated regarding their antimicrobial activity against a broad range of microorganisms including bacteria and yeast. In the present study, the results obtained in the agar diffusion assay are present as average diameter of the materials inhibition zone in Table 3 and Figure 2.
The zeolite- $\mathrm{Cu}^{2+}, \mathrm{Zn}^{2+}, \mathrm{Co}^{2+}$ and $\mathrm{Li}^{+}$showed the best results, where zeolite- $\mathrm{Zn}^{2+}$ inhibited similarly the bacteria and yeast tested in this study. Zeolite- $\mathrm{Cu}^{2+}$ presented higher zone of inhibition against $C$. albicans. In contrast, the zeolite- $\mathrm{Co}^{2+}$ and $\mathrm{Li}^{+}$inhibited the growth of gram positive $S$. aureus relatively higher than others microorganisms.

Only a few studies highlight antifungal effects of ionexchanged zeolites, especially for toxigenic filamentous fungi. Therefore, in previous study performed by Savi et al. ${ }^{\mathbf{1 4}}$ the ion-exchanged zeolites were evaluated against filamentous and toxigenic fungi: Aspergillus flavus, where zeolite with $\mathrm{Li}^{+}$and $\mathrm{Cu}^{2+}$ showed the best antifungal activity. In that study was also performed the antimycotoxin activity test where all zeolite samples (4A zeolite, zeolites with $\mathrm{Li}^{+}, \mathrm{Cu}^{2+}, \mathrm{Co}^{2+}$ and $\mathrm{Zn}^{2+}$ ) efficiently inhibited the aflatoxin $\mathrm{B}_{1}\left(\mathrm{AFB}_{1}\right)$ production by $A$. flavus. Even the zeolite that showed no significant antifungal effect, affected the secondary metabolites $\left(\mathrm{AFB}_{1}\right)$ production of $A$. flavus, suggesting some interaction with the fungi metabolism. Though the mechanisms of antifungal effects of metal ions in fungi are far from being understood in detail, these basic mechanisms enable us to consider the evaluation of antimicrobial effects on cell metabolism from different microorganism including bacterial and yeast. Their efficiency seems to depend on the sensitivity of each species of microorganisms and the interaction with the antimicrobial used.

Similarly to our results, Tekin et al. (2016) shown that the $\mathrm{Zn}^{2+}$ and $\mathrm{Cu}^{2+}$ loaded zeolite samples also exhibited antibacterial activity. The zeolite- $\mathrm{Zn}^{2+}$ and zeolite- $\mathrm{Cu}^{2+}$ showed greater inhibition zone of 13, 15, 10, $20 \mathrm{~mm}$ and 17, 20, 17, $14 \mathrm{~mm}$ for E. coli, S. aureus, P. aeruginosa and $C$. albicans, respectively ${ }^{11}$.

Zeolites- $\mathrm{Ag}^{+}$were found to be the most effective as antibacterial when compared to zeolites exchanged with

Table 3. Average diameter $(\mathrm{mm})$ of the zone of inhibition promoted by $4 \mathrm{~A}$ zeolite $(\mathrm{Z} 4 \mathrm{~A})$ and exchanged zeolites with $\mathrm{Cu}^{2+}, \mathrm{Zn}^{2+}$, $\mathrm{Co}^{2+}, \mathrm{Li}^{+}, \mathrm{La}^{3+}$ and $\mathrm{Ce}^{3+}$ against microorganisms

\begin{tabular}{|l|l|l|l|l|l|l|c|}
\hline \multirow{2}{*}{ Microorganisms } & \multicolumn{7}{|c|}{ Average diameter, $\mathrm{mm}$} \\
\cline { 2 - 9 } & $\mathrm{Z4A}$ & $\mathrm{Cu}^{2+}$ & $\mathrm{Zn}^{2+}$ & $\mathrm{Co}^{2+}$ & $\mathrm{Li}^{+}$ & $\mathrm{La}^{3+}$ & $\mathrm{Ce}^{3+}$ \\
\hline Staphylococcus aureus & 0.0 & 6.0 & 8.5 & 12.0 & 14.5 & 0.0 & 0.0 \\
\hline Escherichia coli & 0.0 & 5.0 & 8.5 & 9.0 & 10.0 & 0.0 & 0.0 \\
\hline Pseudomonas aeruginosa & 0.0 & 7.0 & 9.5 & 11.5 & 12.5 & 0.0 & 0.0 \\
\hline Candida albicans & 0.0 & 10.0 & 9.0 & 11.0 & 11.0 & 0.0 & 0.0 \\
\hline
\end{tabular}

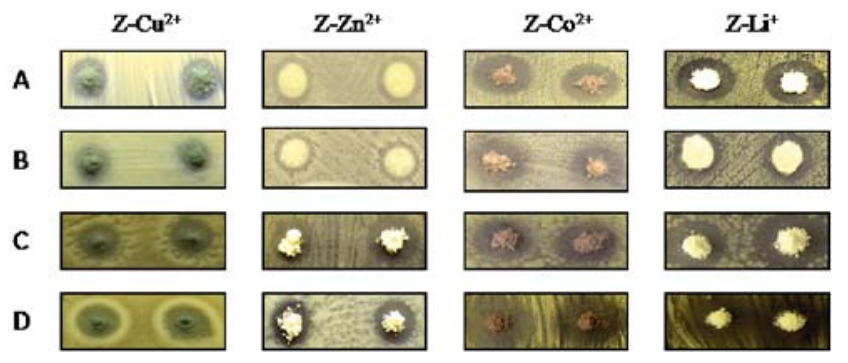

Figure 2. Zone of inhibition around zeolites ion-exchange with $\mathrm{Cu}^{2+}, \mathrm{Zn}^{2+}, \mathrm{Co}^{2+}$ and $\mathrm{Li}^{+}$against (A) S. aureus, (B) E. coli, (C) P. aeruginosa and (D) C. albicans

The standard control (4A zeolite without ion-exchange) has shown no effect against the microorganisms tested and similar results were findings for the zeolites exchange with $\mathrm{La}^{3+}$ and $\mathrm{Ce}^{3+}$.
$\mathrm{Cu}^{2+}$ and $\mathrm{Zn}^{2+}$ according to Demirci et al. (2014). On the other hand, the $\mathrm{Cu}^{2+}$ and $\mathrm{Zn}^{2+}$ ion-loaded zeolites were found to display more antifungal and anticandidal characteristics. Some results that are corroborating to ours, also showed zeolite- $\mathrm{Cu}^{2+}$ is the most effective against $C$. albicans ${ }^{25}$.

It is important to emphasize that these metal ions can be considered as an alternative to safety and stability on antibacterial activity at low concentrations. Zinc is a vital antioxidant and anti-inflammatory agent in the human body, although a small quantity of $\mathrm{Zn}^{2+}$ ion is essential for numerous metabolic activities. Zeolite- $\mathrm{Zn}^{2+}$ have been used in biomedical applications due to their wound healing and bactericidal properties ${ }^{\mathbf{2 6}}$. Similar to zinc, copper is an essential metal for living organisms at low concentrations and are used inorganic antibacterial materials ${ }^{27}$. In recent study, copper doped zeolite 
composite adsorbents showed high efficiency to remove simultaneously heavy metals and total coliforms from wastewater of Akaki river, from central Ethiopia ${ }^{28}$.

In contrast, the antimicrobial activity zeolite loaded of metals as $\mathrm{Co}^{2+}$ and $\mathrm{Li}^{+}$are scarce in the literature, although the $\mathrm{Co}^{2+}$ has already shown antibacterial activity against growth of the Gram-negative bacteria Pseudomonas putida and E. coli when evaluated as two cobalt imidazolate metal-organic frameworks ${ }^{29}$.

The cell survival assays performed are in agreement with the findings of the agar diffusion assay. 4A zeolite had no effect against the microorganisms tested as well the zeolite- $\mathrm{La}^{3+}$ and $\mathrm{Ce}^{3+}$. Zeolites exchanged with $\mathrm{Cu}^{2+}, \mathrm{Li}^{+}$and $\mathrm{Co}^{2+}$ eliminated all living cells in some concentrations tested as shown in Figure 3.

The antimicrobial activity of the ion-exchanged zeolites was shown depending on the concentrations used to each microorganism individually. The zeolite- $\mathrm{Cu}^{2+}$ inhibited the $P$. aeroginosa in the concentration of $6.2 \mathrm{mg} / \mathrm{mL}$ or higher, but the zeolite- $\mathrm{Zn}^{+2}$ had no effect against $P$. aeruginosa. In addition, the action was not complete to other microorganism tested, which presented survival of small amounts of cells. The zeolites with the $\mathrm{Li}^{+}$and $\mathrm{Co}^{+2}$ can be considered the most effective among the six materials tested in the current study, although the ability of $\mathrm{Cu}^{2+}$ is also strong and can be considered effective. The zeolite- $\mathrm{Li}^{+}$shown antibacterial effect against $P$. aeruginosa and $C$. albicans in the concentration from $6.2 \mathrm{mg} / \mathrm{mL}$ while zeolite-Co ${ }^{+}$ inhibited $S$. aureus from $0.7 \mathrm{mg} / \mathrm{mL}$ concentration.

The way ion-exchanged zeolites act as antimicrobial is not yet fully established, mainly by ions as $\mathrm{Co}^{2+}$ and $\mathrm{Li}^{+}$, which have not been yet examined in the literature. However, it is possible to affirm that the zeolite ion re- lease observed in previous study ${ }^{\mathbf{3 0}}$ can get across the cell membrane causing damage to bacteria and fungi ${ }^{\mathbf{3 1}, \mathbf{3 2}}$. This mechanism is well-known for $\mathrm{Cu}^{2+}$ and $\mathrm{Zn}^{2+}$ metal ions.

\section{Toxicological studies}

Artemia sp. is one of the most valuable test organisms available for several applications, including toxicology and ecotoxicology researches ${ }^{20,33,34}$. The toxicity of chemical compounds with possible biological activity has been tested against Artemia sp. due to several advantages such as: well known biology and ecology, low cost of the organisms, as well, speed and convenience of the tests. According to the literature, there is no study involving the evaluation of the toxicity of modified zeolites using this model. However, this microcrustacean is often used as a model organism of toxicity assessment of nanoparticles ${ }^{\mathbf{2 0}, 34}$, iron metallo$\operatorname{drugs}^{33}$, and metal ions of copper and zinc ${ }^{21}$.

As observed in Figure 4, the zeolite ion-exchanged with $\mathrm{Cu}^{2+}, \mathrm{Zn}^{2+}, \mathrm{Co}^{2+}$ and $\mathrm{Li}^{+}$only shown toxic effect to Artemia sp. in concentrations above of $10.7 \mathrm{mg} / \mathrm{mL}$, $96.2 \mathrm{mg} / \mathrm{mL}, 18.5 \mathrm{mg} / \mathrm{mL}$ and $6.2 \mathrm{mg} / \mathrm{mL}$, respectively. Moreover, no mortality was observed within the ion-exchanged zeolites in effective concentrations used for antimicrobial activity.

In the same sense, the L. sativa was used to evaluate the toxicity of the materials. Several studies have reported successful use of L. sativa as bioindicator organisms for ecotoxicological evaluation of contaminated environments ${ }^{35,36}$. In this work, only the zeolite- $\mathrm{Li}^{+}$was capable of causing significant alteration on the germination seeds. The radicle and hypocotyl growth were affected after exposure to almost all the zeolites when used in high concentrations. In the antimicrobial effective con-
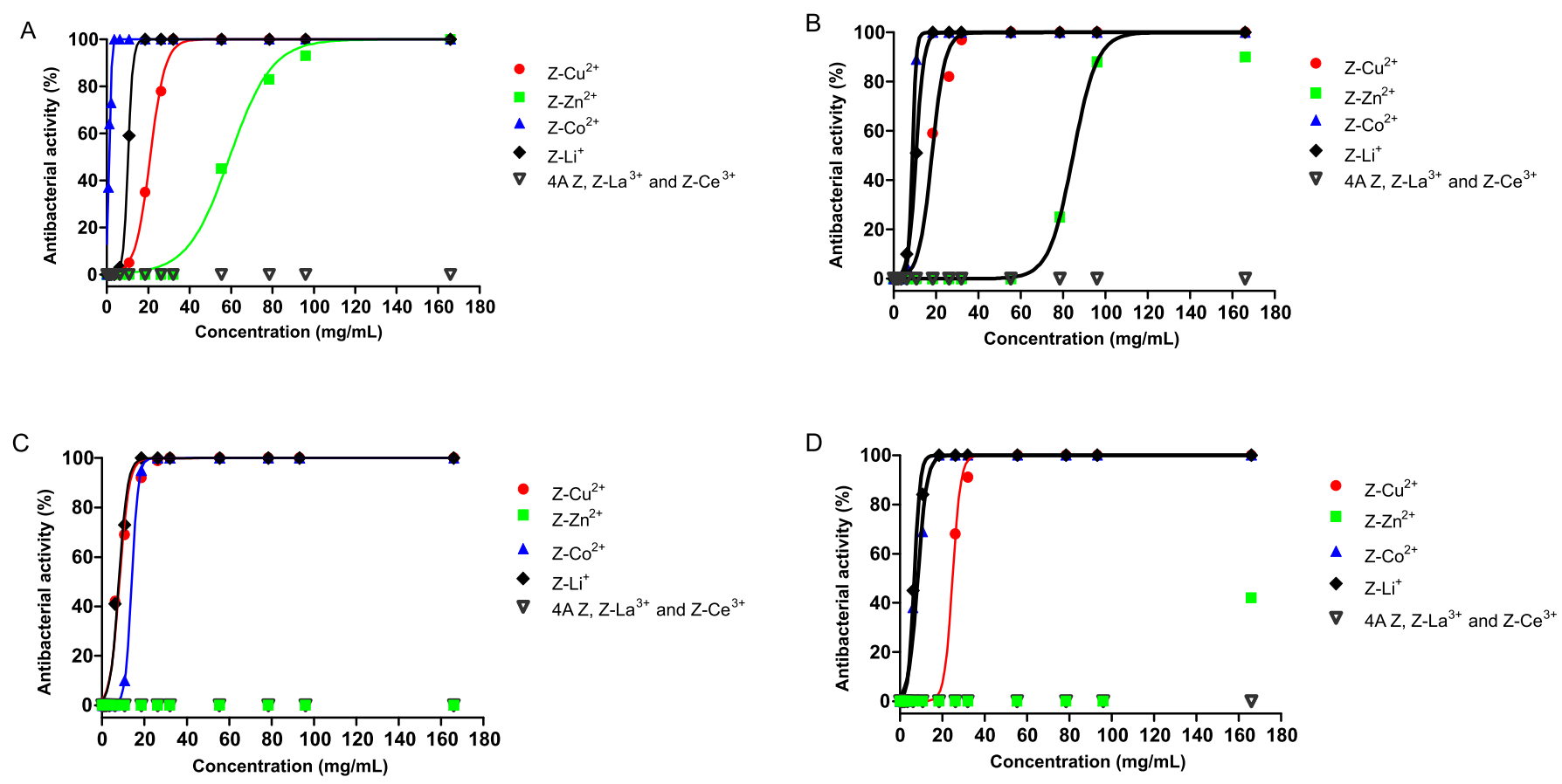

Figure 3. Antibacterial activity (\%) of $4 \mathrm{~A}$ zeolite and zeolites ion-exchange on the bacterial growth: (A) S. aureus, (B), E. coli (C) P. aeruginosa and (D) C. albicans 

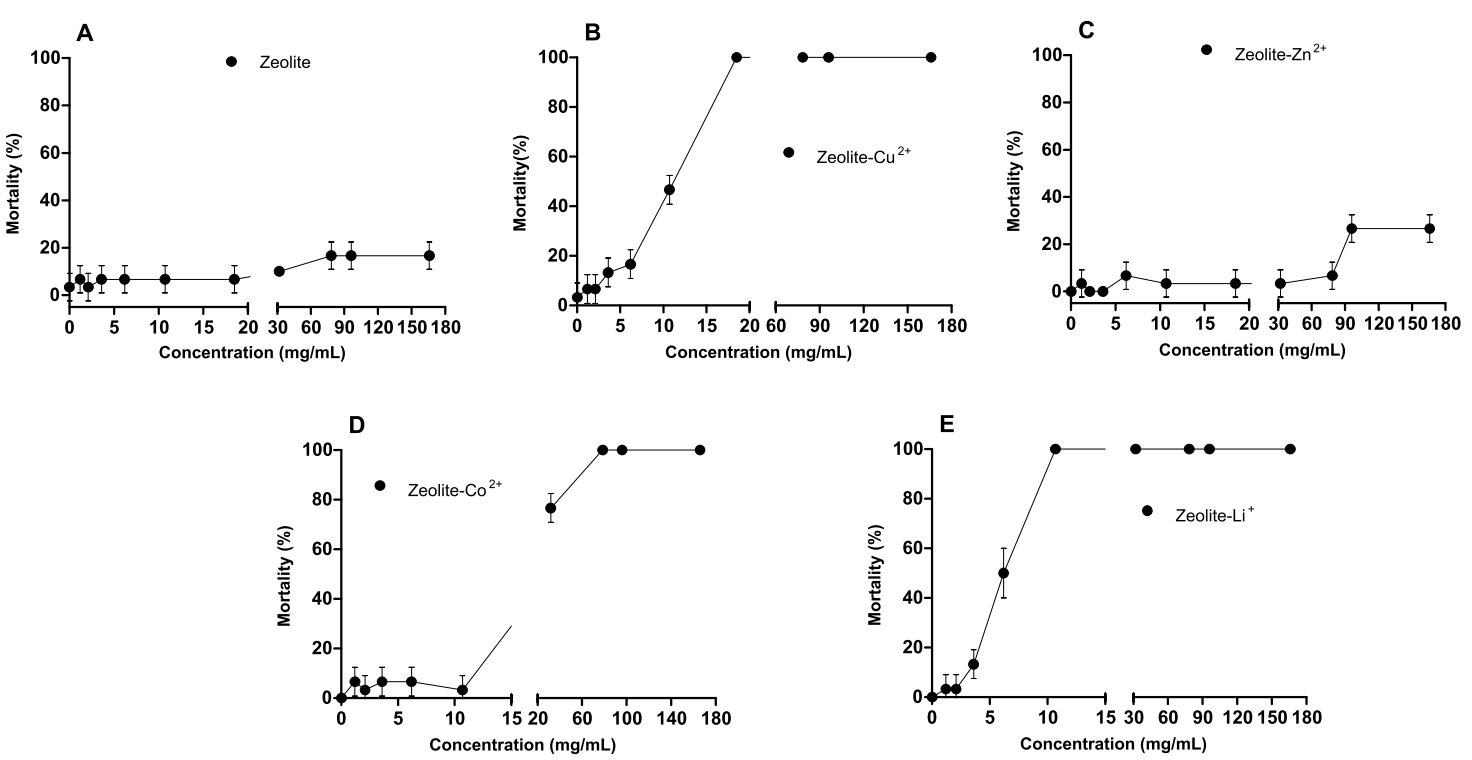

Figure 4. Mortality (\%) of Artemia sp. after $24 \mathrm{~h}$ exposure at 166.6, 96.2, 78.5, 32.1, 18.5, 10.7, 6.2, 3.6, 2.1 and $1.2 \mathrm{mg} / \mathrm{mL}$ concentrations of $4 \mathrm{~A}$ zeolite (A) and its ion-exchanged zeolites with $\mathrm{Cu}^{2+}(\mathrm{B}), \mathrm{Zn}^{2+}(\mathrm{C}), \mathrm{Co}^{2+}$ (D) and $\mathrm{Li}^{+}(\mathrm{E})$
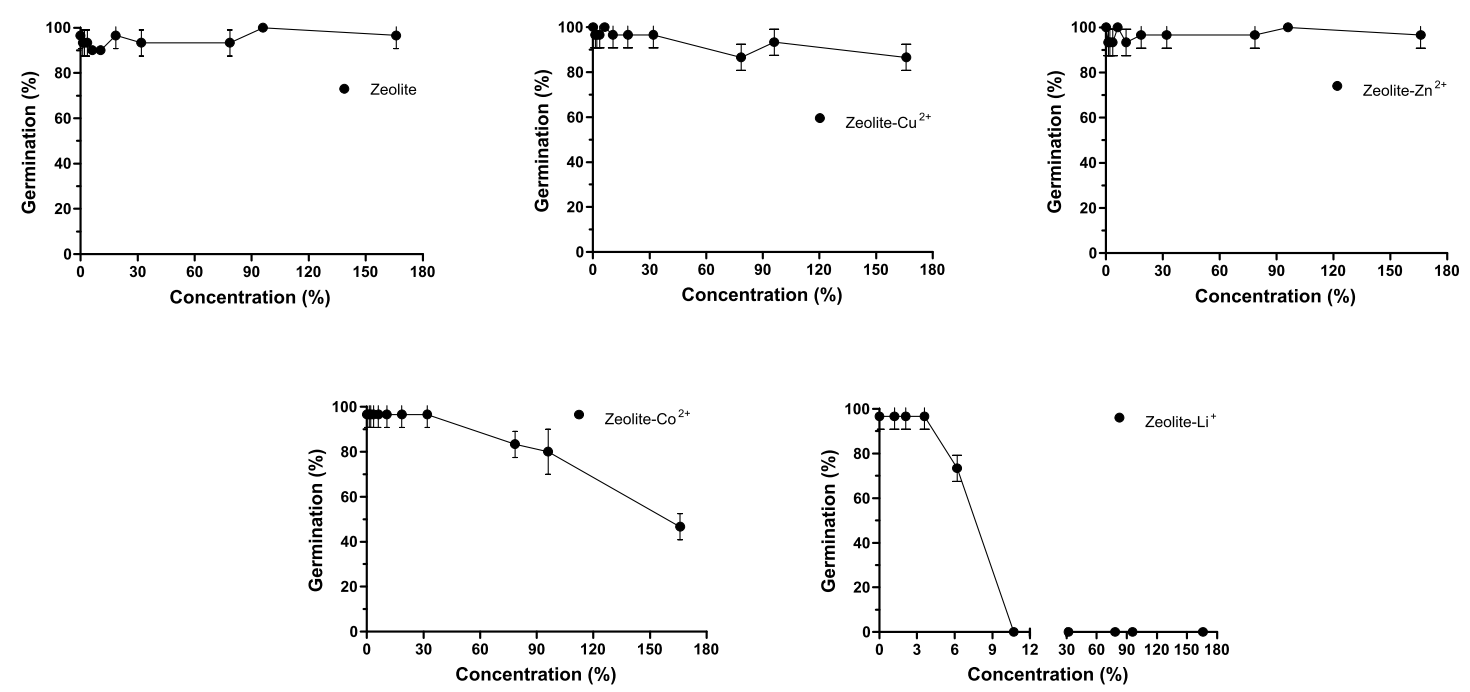

(A)
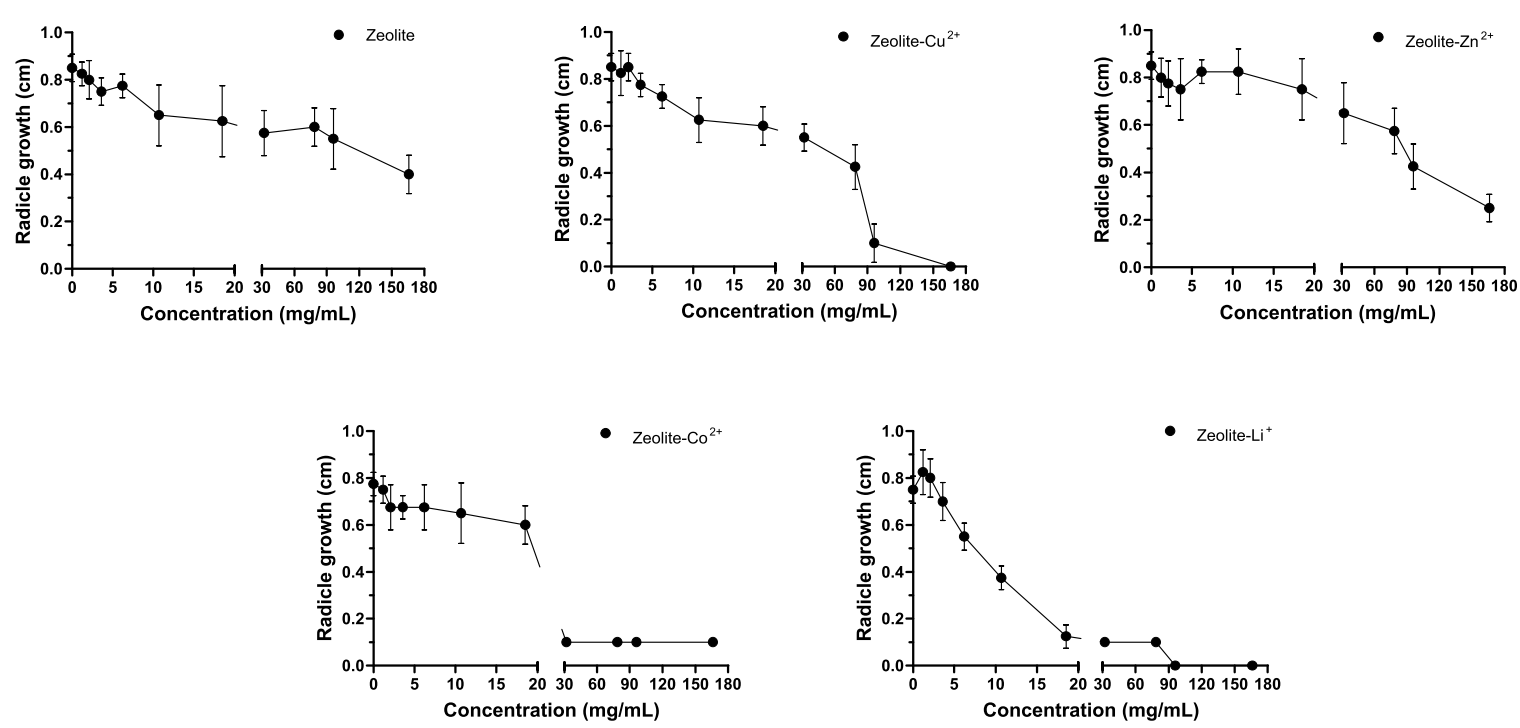

(B) 

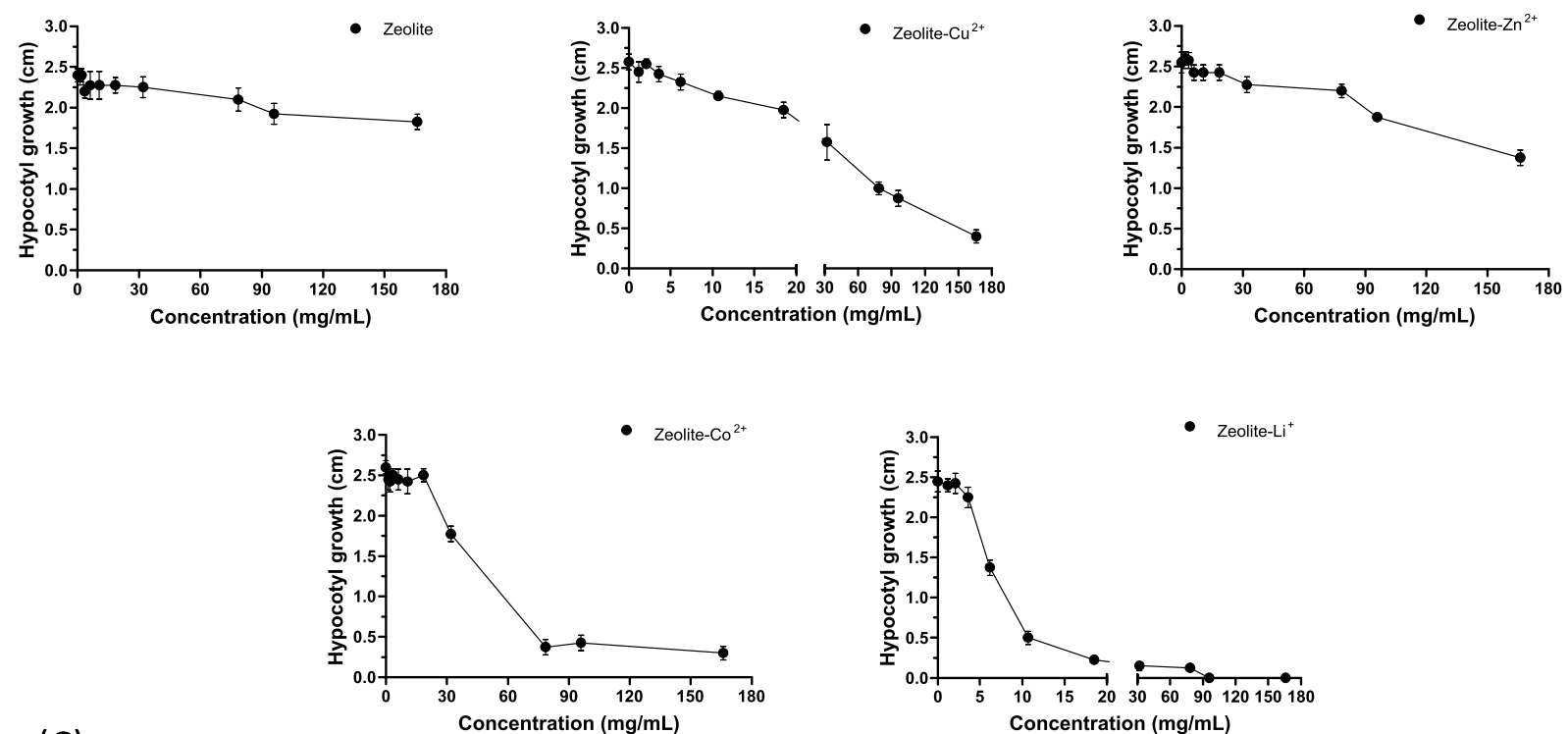

(C)

Figure 5. Sub-chronic toxic effects of the $4 \mathrm{~A}$ zeolite and ion-exchange with $\mathrm{Cu}^{2+}, \mathrm{Zn}^{2+}, \mathrm{Co}^{2+}$ and $\mathrm{Li}^{+}$on seeds of $L$. sativa exposed to different concentration in terms of germination (A), radicle growth (B) and hypocotyl growth (C). Data expressed as mean $\pm \mathrm{SD}$ of three replicates

centrations, the zeolites had presented no toxic effects, with the exception of the zeolite- $\mathrm{Li}^{+}$.

Considering to $L$. sativa seeds germination, only zeolite- $\mathrm{CO}^{2+}$ and $\mathrm{Li}^{+}$showed reduction in the concentrations from 166.6 and $6.2 \mathrm{mg} / \mathrm{mL}$, respectively (Figure $5 \mathrm{~A}$ ). Even after germination of L. sativa, the ions $\mathrm{Cu}^{2+}, \mathrm{Zn}^{2+}$, $\mathrm{Co}^{2+}$ and $\mathrm{Li}^{+}$caused radicle (Figure 5B) and hypocotyls (Figure 5C) growth reduction in concentrations equal or higher than $32.1 \mathrm{mg} / \mathrm{mL}, 96.2 \mathrm{mg} / \mathrm{mL}, 32.1 \mathrm{mg} / \mathrm{mL}$ and $6.2 \mathrm{mg} / \mathrm{mL}$, respectively.

The zeolites presented different result in the plasmid DNA cleavage assay depending on the metal used in their structure as exchange ion. The Figure 6 shows that the $4 \mathrm{~A}$ zeolite $(1 \mathrm{~A})$, zeolite- $\mathrm{Li}^{+}(4 \mathrm{~A})$ and $\mathrm{Co}^{2+}$
(5A) presented no result or cleavage activity that can be observed. The zeolite- $\mathrm{Zn}^{2+}(2 \mathrm{~A})$ presented a slight activity that was visually observed with the increase of FII amount but not statistically significant. On the other hand, the zeolite- $\mathrm{Cu}^{2+}(3 \mathrm{~A})$ presented a strong activity with statistical significance, but probably not by its own feature but due to the highly redox properties of the copper(II) ion $^{37}$ in the presence of HEPES buffer which is well-known to act as reducing agent ${ }^{38}$ leading to the generation of several oxidative species that damages plasmid DNA ${ }^{39,}{ }^{40}$. This hypothesis also explains the lack of DNA cleaving activity of the others zeolites, since those ion metals has none or much lower redox properties compared to copper(II).

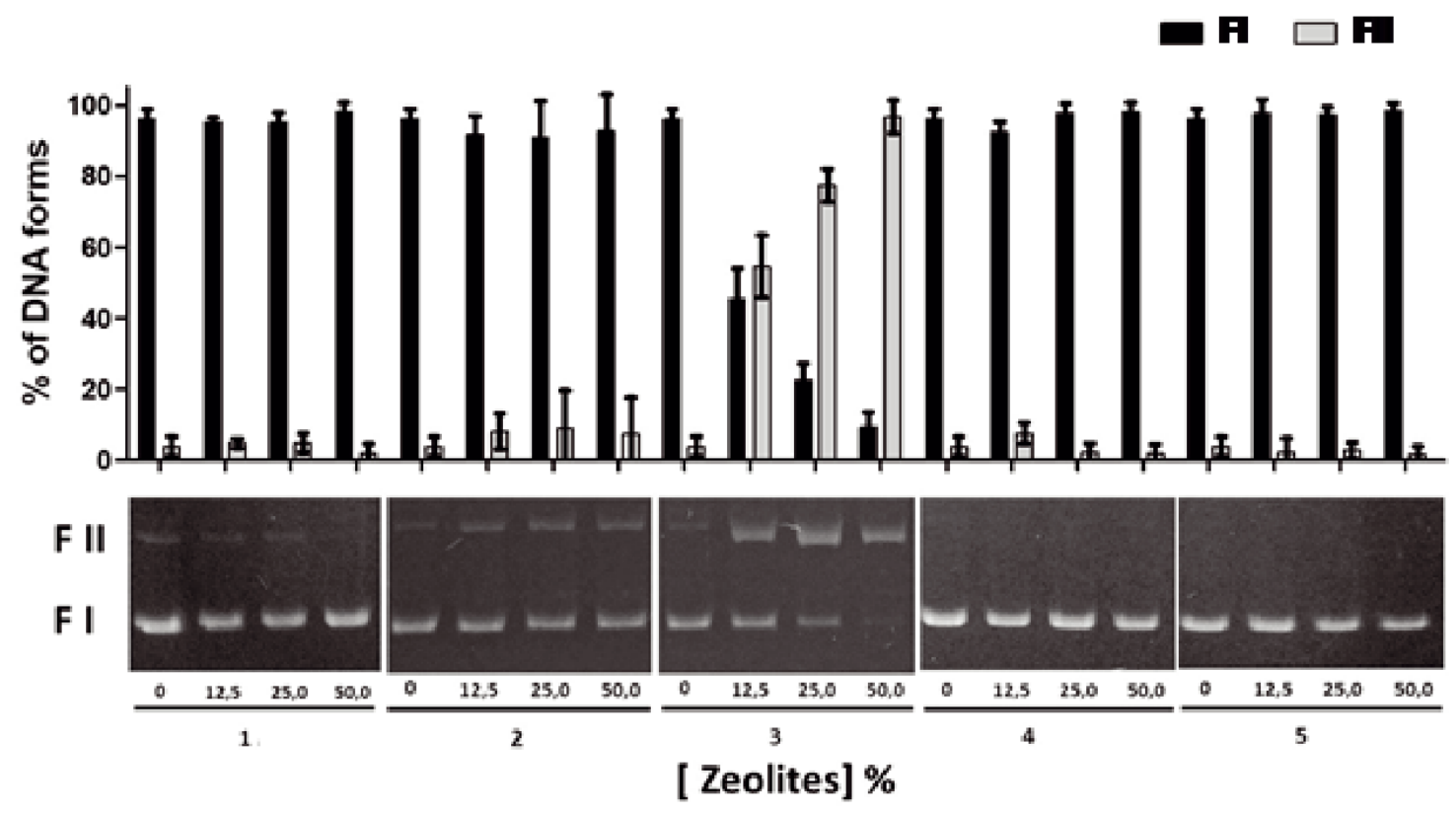

Figure 6. Percentage of DNA forms (FI - uncleaved and FII - single strand cleaved) observed after exposure to different concentrations of (1) $4 \mathrm{~A}$ zeolite and ion-exchange with (2) $\mathrm{Zn}^{2+}$, (3) $\mathrm{Cu}^{2+}$, (4) $\mathrm{Li}^{+}$and (5) $\mathrm{Co}^{2+}$ 


\section{CONCLUSION}

The current study showed that zeolite- $\mathrm{Cu}^{2+}, \mathrm{Li}^{+}$and $\mathrm{Co}^{2+}$ eliminated all living cells in some concentrations tested and were considered the most effective among six materials tested. In the toxicity assays, they affected the Artemia sp. mortality and L. sativa germination when tested in high concentrations. In contrast, it is important to emphasize that the ion-exchanged zeolites showed no toxic effect against Artemia sp. and L. sativa in effective concentrations used for antimicrobial activity. For example, zeolite- $\mathrm{Co}^{2+}$ showed strong antibacterial activity against $S$. aureus in low concentration $(0.7 \mathrm{mg} / \mathrm{mL})$, which showed no alterations against the bioindicators organism and no significant result on plasmid DNA cleavage activity. The ion-exchanged zeolites can be considered promising in terms of potential antimicrobial materials since they presented antibacterial activity in concentrations that are safe for use. Finally, it is important to highlight the efficiency of some ion-exchanged zeolites used to eliminate specific microorganism and therefore, deserve special attention as antimicrobial agent against resistant microorganisms that cause strong impact to public health.

\section{DISCLOSURE STATEMENT}

No potential conflict of interest was reported by the authors.

\section{ACKNOWLEDGEMENTS}

We acknowledge funding from a CNPq scholarship in PIBIT mode.

\section{LITERATURE CITED}

1. Boschetto, D.L., Lerin, L., Cansian, R., Pergher, S.B.C. \& Di Luccio, M. (2012). Preparation and antimicrobial activity of polyethylene composite films with silver exchanged zeolite-Y. Chem. Eng. J. 204, 210-216. http://dx.doi.org/10.1016/j. cej.2012.07.111

2. Sánchez, M.J., Mauricio, J.E., Paredes, A.R., Gamero, P. \& Cortés, D. (2017). Antimicrobial properties of ZSM-5 type zeolite functionalized with silver. Mater. Lett. 191, 65-68. http:// dx.doi.org/10.1016/j.matlet.2017.01.039

3. Gazzotti, S., Todisco, S.A., Picozzi, C., Ortenzi, M.A., Farina, H., Lesma, G. \& Silvani, A. (2019). Eugenol-grafted aliphatic polyesters: Towards inherently antimicrobial PLA-based materials exploiting OCAs chemistry. Eur. Polym. J. 114, 369-379. https://doi.org/10.1016/j.eurpolymj.2019.03.001

4. Turalija, M., Bischof, S., Budimir, A. \& Gaan, S. (2016). Antimicrobial PLA films from environment friendly additives. Compos. Part B: Engin. 102, 94-99. https://doi.org/10.1016/j. compositesb.2016.07.017

5. Braunwarth, H. \& Brill, F.H.H. (2014). Antimicrobial efficacy of modern wound dressings: Oligodynamic bactericidal versus hydrophobic adsorption effect. Wound Medicine. 5, 16-20. http://dx.doi.org/10.1016/j.wndm.2014.04.003

6. Breck, D.W. (1984). Zeolite molecular sieves: structure, chemistry, and use ed (Universidade de Michigan), pp. 771.

7. McCusker, L.B., Olson, D.H. \& Baerlocher, C. (2007). Atlas of Zeolite Framework Types $6^{\mathrm{a}}$ ed (Elsevier Science). ISBN: 978-0-444-53064-6.

8. Kulprathipanja, S. (2010). Zeolites in Industrial Separation and Catalysis. pp. 618. Wiley.

9. Melo, C.R., Riella, H.G., Kuhnen, N.C., Angioletto, E., Melo, A.R., Bernardin, A.M., da Rocha, M.R. \& da Silva,
L. (2012). Synthesis of 4A zeolites from kaolin for obtaining $5 \mathrm{~A}$ zeolites through ionic exchange for adsorption of arsenic. Mater. Sci. Engin., B. 177(4), 345-349. http://dx.doi.org/10.1016/j. mseb.2012.01.015

10. Rivera-Garza, M., Olguín, M.T., García-Sosa, I., Alcántara, D. \& Rodríguez-Fuentes, G. (2000). Silver supported on natural Mexican zeolite as an antibacterial material. Micropor. Mesopor. Mat. 39(3), 431-444. http://dx.doi.org/10.1016/S13871811(00)00217-1

11. Tekin, R. \& Bac, N. (2016). Antimicrobial behavior of ion-exchanged zeolite X containing fragrance. Micropor. Mesopor. Mat. 234, 55-60. http://dx.doi.org/10.1016/j.micromeso.2016.07.006

12. Ferreira, L., Fonseca, A.M., Botelho, G., Aguiar, C.A. \& Neves, I.C. (2012). Antimicrobial activity of faujasite zeolites doped with silver. Micropor. Mesopor. Mat. 160, 126-132. http:// dx.doi.org/10.1016/j.micromeso.2012.05.006

13. Fang, M., Chen, J.H., Xu, X.L., Yang, P.H. \& Hildebrand, H.F. (2006). Antibacterial activities of inorganic agents on six bacteria associated with oral infections by two susceptibility tests. Int. J. Antimicrob. Agents. 27(6), 513-517. http://dx.doi. org/10.1016/j.ijantimicag.2006.01.008

14. Kalinowska, M., Piekut, J., Bruss, A., Follet, C., Sienkiewicz-Gromiuk, J., Świsłocka, R., Rzączyńska, Z. \& Lewandowski, W. (2014). Spectroscopic (FT-IR, FT-Raman, 1H, 13C NMR, UV/VIS), thermogravimetric and antimicrobial studies of $\mathrm{Ca}(\mathrm{II}), \mathrm{Mn}(\mathrm{II}), \mathrm{Cu}(\mathrm{II}), \mathrm{Zn}(\mathrm{II})$ and $\mathrm{Cd}(\mathrm{II})$ complexes of ferulic acid. Spectrochim. Acta. A Mol. Biomol. Spectrosc. 122, 631-638. http://dx.doi.org/10.1016/j.saa.2013.11.089

15. Zhang, B., Lin, Y., Tang, X., He, S. \& Xie, G. (2010). Synthesis, characterization, and antimicrobial properties of $\mathrm{Cu}$-inorganic antibacterial material containing lanthanum. J. Rare Earths. 28, 451-455. http://dx.doi.org/10.1016/S10020721(10)60346-8

16. Savi, G.D., Cardoso, W.A., Furtado, B.G., Bortolotto, T., Da Agostin, L.O.V., Nones, J., Zanoni, E.T., Montedo, O.R.K. \& Angioletto, E. (2017). New ion-exchanged zeolite derivatives: Antifungal and antimycotoxin properties against Aspergillus flavus and aflatoxin $\mathrm{B}_{1}$. Mat. Res. Exp., 4, 085401. http://dx.doi.org/10.1088/2053-1591/aa84a5

17. CLSI (2009). Clinical and Laboratory Standards Institute. Performance standards for antimicrobial disk susceptibility tests. Pennsylvania, USA., Wayne.

18. Balouiri, M., Sadiki, M. \& Ibnsouda, S.K. (2016). Methods for in vitro evaluating antimicrobial activity: A review. J. Pharmaceut. Anal. 6(2), 71-79. http://dx.doi.org/10.1016/j. jpha.2015.11.005

19. Santos, M.F., Oliveira, C.M., Tachinski, C.T., Fernandes, M.P., Pich, C.T., Angioletto, E., Riella, H.G. \& Fiori, M.A. (2011). Bactericidal properties of bentonite treated with $\mathrm{Ag}+$ and acid. Int. J. Miner. Process. 100(1), 51-53. http://dx.doi. org/10.1016/j.minpro.2011.04.012

20. Rajabi, S., Ramazani, A., Hamidi, M. \& Naji, T. (2015). Artemia salina as a model organism in toxicity assessment of nanoparticles. DARU J. Pharm. Sci. 23(1), 20. http://dx.doi. org/10.1186/s40199-015-0105-x

21. Brix, K.V., Gerdes, R.M., Adams, W.J. \& Grosell, M. (2006). Effects of copper, cadmium, and zinc on the hatching success of brine shrimp (Artemia franciscana). Arch. Environ. Contam. Toxicol. 51(4), 580-583. http://dx.doi.org/10.1007/ s00244-005-0244-z

22. Charles, J., Sancey, B., Morin-Crini, N., Badot, P.-M., Degiorgi, F., Trunfio, G. \& Crini, G. (2011). Evaluation of the phytotoxicity of polycontaminated industrial effluents using the lettuce plant (Lactuca sativa) as a bioindicator. Ecotoxicol. Environ. Saf. 74(7), 2057-2064. https://doi.org/10.1016/j.ecoenv.2011.07.025

23. Netto, E., Madeira, R.A., Silveira, F.Z., Fiori, M.A., Angioleto, E., Pich, C.T. \& Geremias, R. (2013). Evaluation of the toxic and genotoxic potential of acid mine drainage using physicochemical parameters and bioassays. Environ. 
Toxicol. Pharmacol. 35(3), 511-516. http://dx.doi.org/10.1016/j. etap.2013.02.007

24. Luna, F.J. \& Schuchardt, U. (2001). Modificação de zeólitas para uso em catálise. Quim. Nova. 24, 885-892.

25. Demirci, S., Ustaoglu, Z., Yilmazer, G.A., Sahin, F. \& Bac, N. (2014). Antimicrobial properties of zeolite-X and zeolite-A ion-exchanged with silver, copper, and zinc against a broad range of microorganisms. Appl. Biochem. Biotechnol. 172(3), 1652-1662. http://dx.doi.org/10.1007/s12010-013-0647-7

26. Tapiero, H. \& Tew, K.D. (2003). Trace elements in human physiology and pathology: zinc and metallothioneins. Biomed. Pharmacother. 57(9), 399-411.

27. Alswat, A.A., Ahmad, M.B., Hussein, M.Z., Ibrahim, N.A. \& Saleh, T.A. (2017). Copper oxide nanoparticles-loaded zeolite and its characteristics and antibacterial activities. $J$. Mater. Sci. Technol. 33(8), 889-96. http://dx.doi.org/10.1016/j. jmst.2017.03.015

28. Fanta, F.T., Dubale, A.A., Bebizuh, D.F. \& Atlabachew, M. (2019). Copper doped zeolite composite for antimicrobial activity and heavy metal removal from waste water. $B M C$ Chemistry. 13(1), 44. http://dx.doi.org/10.1186/s13065-019-0563-1

29. Aguado, S., Quirós, J., Canivet, J., Farrusseng, D., Boltes, K. \& Rosal, R. (2014). Antimicrobial activity of cobalt imidazolate metal-organic frameworks. Chemosphere. 113, 188-192. http://dx.doi.org/10.1016/j.chemosphere.2014.05.029

30. Savi, G.D., Cardoso, W.A., Furtado, B.G., Bortolotto, T., Zanoni, E.T., Scussel, R., Rezende, L.F., Avila, R.A.M., Montedo, O.R.K. \& Angioletto, E. (2018). Antifungal activities against toxigenic Fusarium specie and deoxynivalenol adsorption capacity of ion-exchanged zeolites. J. Environ. Sci. Health, Part B, 53(3): 184-190. http://dx.doi.org/ 10.1080/03601234.2017.1405639.

31. Tamayo, L., Azócar, M., Kogan, M., Riveros, A. \& Páez, M. (2016). Copper-polymer nanocomposites: An excellent and cost-effective biocide for use on antibacterial surfaces. Mater. Sci. Engin.: C. 69, 1391-1409. http://dx.doi.org/10.1016/j. msec.2016.08.041

32. Savi, G.D., Bortoluzzi, A.J. \& Scussel, V.M. (2013). Antifungal properties of Zinc-compounds against toxigenic fungi and mycotoxin. Int. J. Food Sci. Technol. 48(9), 1834-1840. http://dx.doi.org/10.1111/ijfs.12158

33. Vitorino, H.A., Mantovanelli, L., Zanotto, F.P. \& Esposito, B.P. (2015). Iron metallodrugs: stability, redox activity and toxicity against Artemia salina. PLoS One. 10(4), e0121997. http://dx.doi.org/10.1371/journal.pone.0121997

34. Arulvasu, C., Jennifer, S.M., Prabhu, D. \& Chandhirasekar, D. (2014). Toxicity effect of silver nanoparticles in brine shrimp Artemia. Sci. World J.2014, 256919. http://dx.doi. org/10.1155/2014/256919

35. Bortolotto, T., Bertoldo, J.B., da Silveira, F.Z., Defaveri, T.M., Silvano, J. \& Pich, C.T. (2009). Evaluation of the toxic and genotoxic potential of landfill leachates using bioassays. Environ. Toxicol. Pharmacol. 28(2), 288-293. http://dx.doi. org/10.1016/j.etap.2009.05.007

36. Rodrigues, L.C.d.A., Barbosa, S., Pazin, M., Maselli, B.d.S., Beijo, L.A. \& Kummrow, F. (2013). Fitotoxicidade e citogenotoxicidade da água e sedimento de córrego urbano em bioensaio com Lactuca sativa. Rev. Bras. Eng. Agríc. 17, 1099-1108.

37. Angele-Martinez, C., Nguyen, K.V., Ameer, F.S., Anker, J.N. \& Brumaghim, J.L. (2017). Reactive oxygen species generation by copper(II) oxide nanoparticles determined by DNA damage assays and EPR spectroscopy. Nanotoxicology. 11(2), 278-288. http://dx.doi.org/10.1080/17435390.2017.1293750

38. Wang, F. \& Sayre, L.M. (1989). Oxidation of tertiary amine buffers by copper(II). Inorg. Chem. 28(2), 169-170. http://dx.doi.org/10.1021/ic00301a001

39. Tachon, P. (1989). Ferric and cupric ions requirement for DNA single-strand breakage by $\mathrm{H} 2 \mathrm{O} 2$. Free Radic. Res. Commun. 7(1), 1-10.
40. Burrows, C.J. \& Muller, J.G. (1998). Oxidative Nucleobase Modifications Leading to Strand Scission. Chem. Rev. 98(3), 1109-1152. 